\title{
The cause of bark stripping of young plantation trees
}

\section{T. C. R. White ${ }^{1}$ (1)}

Received: 17 June 2019 / Accepted: 24 September 2019/Published online: 5 November 2019

(C) INRA and Springer-Verlag France SAS, part of Springer Nature 2019

\begin{abstract}
- Key message Herbivorous mammals, from small voles to large ungulates, strip and eat the bark of young plantation trees. They do this most frequently at times when sources of protein food that can support their reproduction and lactation are in short supply. Furthermore, they preferentially attack —often repeatedly — trees that have experienced some form of environmental stress, leaving neighbouring trees untouched. Such stressed trees carry higher levels of amino acids in their phloem. These facts, coupled with the similarly timed and selective harvesting of bark phloem by some Australia marsupials and Northern Hemisphere woodpeckers indicate that it is the trees' protein-enriched phloem that the bark strippers are seeking.
\end{abstract}

Keywords Amino acids · Cambium feeders · Drought $\cdot$ Environmental stress $\cdot$ Marsupial gliders $\cdot$ Nitrogen nutrition . Woodpeckers

Foresters all over the world are, from time to time, plagued by the stripping of bark from young plantation trees of a variety of both broadleaf and conifer species. The damage inflicted can vary from minor scarring through serious deformation of the trunk to death of the tree. The stripping is done by a diverse range of herbivorous mammals from large ruminants to small rodents, and occasionally by birds. Descriptions, discussions and reviews of this behaviour are readily available in the literature (Andreev 1988; Baxter and Hansson 2001; Gill 1992a, b; Klich 2017; Mansson and Jarnemo 2013; Motta 1996; Silcock 2018), and it is not the purpose of this short communication to add to this. Rather it presents a hypothesis based on evidence from studies of different but related bark feeding behaviours that reveal the likely common cause for this stripping behaviour.

The stripping happens mostly in late winter and early spring, when the sap flow of the trees is increasing and when the animals are most likely to be short of sufficient protein food to support spring reproduction and lactation (Andreev 1988; Beeson 1989; Bucyanayandi et al. 1992; Hansson

Handling Editor: Aurélien Sallé

T. C. R. White

tcrwhite@optusnet.com.au

1 School of Agriculture Food and Wine, Waite Agricultural Research Institute, The University of Adelaide, Glen Osmond South Australia 5064 Australia
1986; Hornfeldt et al. 1986). Nor is this behaviour a random process. Certain trees are selected—often repeatedly—while others are left untouched (Mansson and Jarnemo 2013; Welch et al. 1987). Selected trees tend to be faster growing ones with thicker cambium and when the flow of their phloem sap is at a peak. But in addition, it is trees growing on poor soils or other stressful sites such as sun-exposed aspects or those stressed by ground fire or drought (Brockley and Elmes 1987; Camperio Ciani et al. 2001; Mori et al. 2015; Nichols et al. 2016), and trees that have been fertilized with nitrogen or are grafted and in poor condition (Pulliainen and Tunkkari 1987; Rousi et al. 1987). All such preferentially selected trees would have higher levels of nutrients, particularly amino acids, in their phloem as a result of the stress (Eberhardt 2000; Faber 1996; Miguelle and Van Ballenberghe 1989; White 1984).

Generally, the not unreasonable assumption is that animals that strip and eat bark are seeking some essential nutrient, trace element, or mineral that is lacking in their diet (Camperio Ciani et al. 2001; Nichols et al. 2016; Welch et al. 1987). Most commonly, this is thought to be sodium, and Au et al. (2018) have demonstrated one case where this would seem to be so. They found that a population of the Australian koala, Phascolarctos cinereus, eats the bark of eucalyptus trees growing in a sub-alpine region where the foliage of the trees (normally, the sole source of food for the koalas) has very low levels of sodium but relatively much higher levels in the bark. The koalas bite off and eat pieces of bark but do not penetrate through to the cambium beneath. 
Some other bark-feeding animals are found to take only the outer bark. One of these is a small Indonesian squirrel, Sundasciurus lowii (Whitten and Whitten 1987). But what it is they are getting from this has not been demonstrated.

However, the significant thing about this feeding is that it is quite different from bark stripping. These animals are feeding on the dead bark of mature trees, whereas those that strip the bark from young trees take the still-living soft bark, exposing and eating the cambium tissues beneath. And it is access to the phloem in the cambium that strippers are seeking.

There is, however, a third - and more sophisticated - type of bark feeding that closely equates with bark stripping and provides strong evidence as to what is truly driving all these different animals to strip the bark off young trees.

The Australian sugar glider, Petaurus breviceps, and yellow-bellied glider, $P$. australis, both cut grooves in the bark of eucalyptus trees and lap the exuding phloem sap. Both rely primarily on insects as a source of protein for reproduction in the spring, but during winter, when insects are least available, they mostly eat sap, returning repeatedly to open existing cuts and cut new ones, presumably to maintain their minimum protein requirements needed for maintenance and reproduction (Smith 1982).

A second and even more sophisticated form of this type of bark feeding is that performed by different species of Eurasian and North America woodpeckers. While this behaviour has long been known, a recent comprehensive review of it combined with a detailed study of it by the Eurasian three-toed woodpecker, Picoides tridactylus, (Pakkala et al. 2018) has demonstrated its extent and adaptive function. In late winter and early spring at the beginning of the breeding season, when their basic food source of arthropods is low, these birds spend up to a third of their foraging time feeding on the phloem of several species of conifer and hardwood trees. They peck horizontal rows of holes through to the phloem of the trees' boles and feed on the exuding sap. They concentrate this feeding repeatedly over the years on a relatively few trees, reopening existing holes and cutting new ones. And they concentrate on those trees exposed to direct sunlight on the south-facing edges of the forest, and on trees that are in poor health or have been physically damaged, including by scorching of their boles during controlled ground fire (Pakkala et al. 2017). All these selected trees will have been stressed and consequently have higher levels of amino acid nitrogen in the phloem of their boles (Eberhardt 2000; White 1984).

Phloem provides a nutrient-rich food that is "pre-digested" (i.e. already broken down to a form that can be immediately absorbed for growth) and largely "un-defended", lacking toxins and feeding deterrents. It provides both sugars as a source of energy and amino acids for building protein. Its concentration of nutrients can differ considerably both from species to species and over time, being most concentrated when trees are actively growing or stressed. In flowering plants, nitrogen content can be 30 times higher than in nonflowering ones (Blevin 1989; Danell et al. 1985; Douglas 2006). Phloem is principally exploited by sap-sucking insects (Douglas 2006) but also by cambium-feeding wood-boring and bark beetles (White 2015) and, to a lesser extent, by early instar larval Lepidoptera (White 2018), so it is not surprising that mammals suffering a shortage of good food turn to eating plant phloem as a substitute source or protein.

Authors' contributions The author conceived and wrote down the manuscript

Data availability Data sharing not applicable to this article as no datasets were generated or analysed during the current study.

\section{Compliance with ethical standards}

Conflicts of interest The author declares no that he has no conflict of interest.

\section{References}

Andreev A (1988) The ten year cycle of the winter grouse of Lower Kolyma. Oecologia 76:261-267

$\mathrm{Au}$ J, Youngentob KN, Clark RG, Phillips R, Foley WJ (2018) Bark chewing reveals nutrient limitation of leaves for a specialist folivore. J Mammal 98:1192-2017

Baxter R, Hansson L (2001) Bark consumption by small rodents in the northern and southern hemispheres. Mammal Rev 31:47-59

Beeson M (1989) Seasonal dietary stress in a forest monkey (Cercopithecus mitis). Oecologia 78:565-570

Blevin DG (1989) An overview of nitrogen metabolism in higher plants. In: Poulton JE, Romeo JT, Conn EC (eds) Plant nitrogen metabolism. Plenum Press, New York, pp 1-41

Brockley RP, Elmes E (1987) Barking damage by red squirrels on juvenile-spaced lodgepole pine stands in south-central British Columbia. For Chron 63:28-31

Bucyanayandi J-D, Bergeron J-M, Souci J, Thomas DW, Jean Y (1992) Differences in nutritional quality between herbaceous plants and bark of conifers as winter food for the vole Microtus pennsylvanicus. J Appl Ecol 29:371-377

Camperio Ciani A, Martinoli L, Capiluppi C, Arahou M, Mouna M (2001) Effects of water availability and habitat quality on barkstripping behavior in Barbary Macaques. Conserv Biol 15:259-265

Danell K, Elmqvist T, Ericson L, Salomonson A (1985) Sexuality in willows and preference by bark-eating voles: defence or not? Oikos 44:82-90

Douglas AE (2006) Phloem sap feeding by animals: problems and solutions. J Exp Bot 57:747-754

Eberhardt LS (2000) Use and selection of sap trees by yellow-bellied sap suckers. Auk 117:41-51

Faber WE (1996) Bark stripping by moose on young Pinus sylvestris in south-central Sweden. Scand J For Res 11:300-306

Gill RM (1992a) A review of damage by mammals in north temperate forests.1. Deer. Forestry 65:145-169

Gill RM (1992b) A review of damage by mammals in north temperate forests.2. Small mammals. Forestry 65:281-308

Hansson L (1986) Bark consumption of voles in relation to snow cover, population density and grazing impact. Holarct Ecol 9:312-316 
Hornfeldt B, Lofgren O, Carlsson B-G (1986) Cycles in voles and small game in relation to variations in plant production indices in northern Sweden. Oecologia 68:496-502

Klich D (2017) Selective bark stripping of various tree species by Polish horses in relation to bark detachability. For Ecol Manag 384:65-71

Mansson J, Jarnemo A (2013) Bark-stripping on Norway spruce by red deer in Sweden: level of damage and relation to tree characteristics. Scan J For Res 28:117-125

Miguelle DG, Van Ballenberghe V (1989) Impact of bark stripping by moose on aspen-spruce communities. J Wildl Manag 53:577-587

Mori E, Mazzoglio PJ, Rima PC, Aloise G, Bertolino S (2015) Bark stripping damage by Callosciurus finlaysonii introduced into Italy. Mammalia 80:507-514

Motta R (1996) Impact of wild ungulates on forest regeneration and tree composition of mountain forests in the Western Italian Alps. For Ecol Manag 88:93-98

Nichols CP, Drewe JA, Gill R, Goode N, Gregory N (2016) A novel causal mechanism for grey squirrel bark stripping: the calcium hypothesis. For Ecol Manag 367:12-20

Pakkala T, Kouki J, Piha M, Tiainen J (2017) Phloem sap in fire-damaged Scots pine trees provides instant foraging opportunities for threetoed woodpeckers Picoides tridactylus. Ornis Svecica 27:144-149

Pakkala T, Piiroinen J, Lakka J, Tiainen J, Pina M, Kouki J (2018) Tree sap as an important seasonal food resource for woodpeckers: the case of the Eurasian three-toed woodpecker (Picoides tridactylus) in southern Finland. Ann Zool Fenn 55:79-92
Pulliainen E, Tunkkari PS (1987) Winter diet, habitat selection and fluctuation of a mountain hare Lepus timidus population in Finnish Forest Lapland. Holarct Ecol 10:261-267

Rousi M, Haggman J, Bryant JP (1987) The effect of bark phenols upon mountain hare barking of winter-dormant Scots pine. Holarct Ecol 10:80-64

Silcock P (2018) The coast redwood science symposium. NZ J For 63: $35-37$

Smith AP (1982) Diet and feeding strategies of the marsupial sugar glider in temperate Australia. J Anim Ecol 51:149-166

Welch D, Staines BW, Scott D, Catt DC (1987) Bark stripping damage by red deer on a sitka spruce forest in western Scotland. I. Incidence. Forestry 60:249-262

White TCR (1984) The abundance of invertebrate herbivores in relation to the availability of nitrogen in stressed food plants. Oecologia 63: $90-105$

White TCR (2015) Are outbreaks of cambium-feeding beetles generated by nutritionally enhanced phloem of drought-stressed trees? J Appl Entomol 139:567-578

White TCR (2018) An alternative hypothesis explains outbreaks of conifer-feeding budworms of the genus Choristoneura (Lepidoptera: Tortricidae) in Canada. J Appl Entomol 142:725-730

Whitten JEJ, Whitten AJ (1987) Analysis of bark eating in a tropical squirrel. Biotropica 19:107-115

Publisher's note Springer Nature remains neutral with regard to jurisdictional claims in published maps and institutional affiliations. 